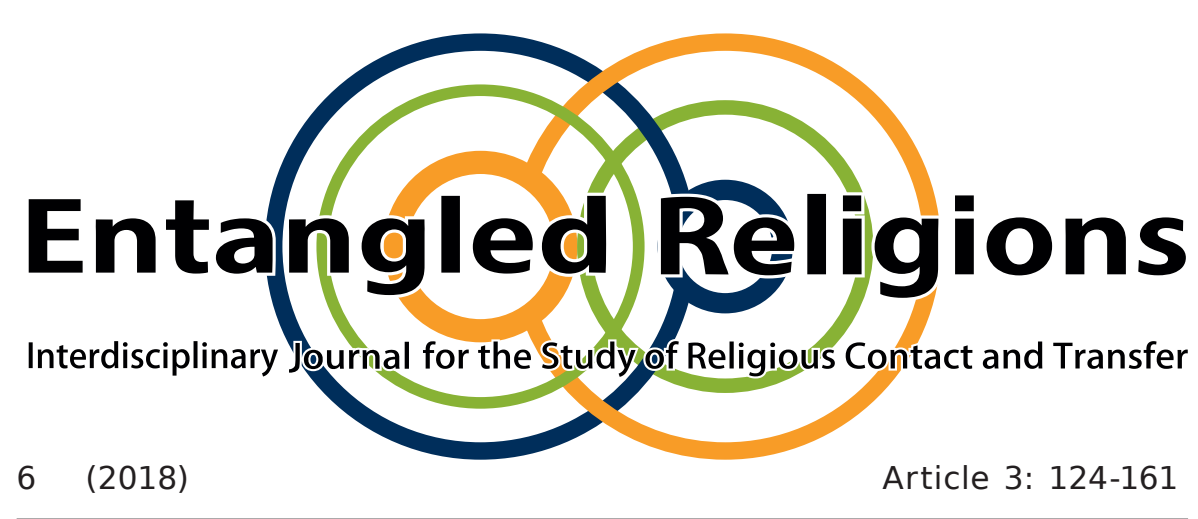

\title{
The Jewish-Christian Polemics in the Sermons of R. Shaul Serero of Fes (1566-1655)
}

\section{MICHAL OHANA}

Bar Ilan University, Ramat Gan, Israel

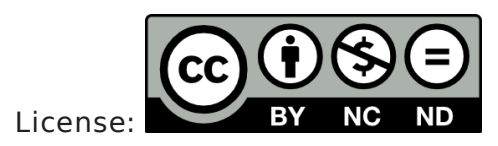

This contribution to Entangled Religions is published under the Creative Commons Attribution-NonCommercial-NoDerivatives 4.0 International Public License (CC BY-NC-ND 4.0 International). The license can be accessed at http://creativecommons.org/licenses/ by-nc-nd/4.0/ or is available from Creative Commons, 559 Nathan Abbot Way, Stanford, California 94305, USA.

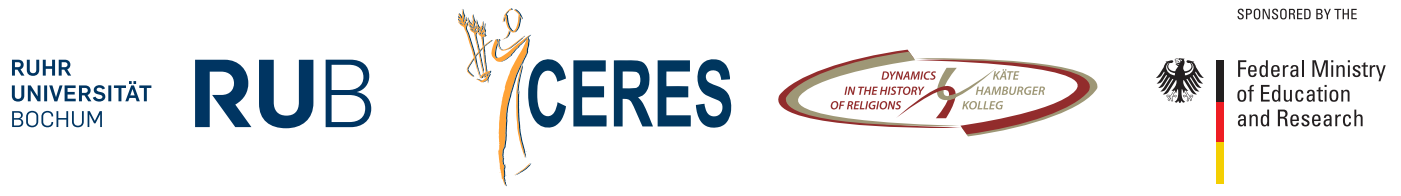




\title{
The Jewish-Christian Polemics in the Sermons of R. Shaul Serero of Fes (1566-1655)
}

\author{
MICHAL OHANA
}

Bar Ilan University, Israel

\begin{abstract}
R. Shaul Serero (1566-1655) served as the chief rabbi of Fes during the first half of the seventeenth century. Serero repeatedly devoted his annual sermons on the Sabbath preceding Passover to clarifying various aspects of the concept of redemption, one of the main subjects of the Jewish-Christian polemic. A review of these sermons reveals that Serero found it necessary to examine and refute the Christian dogma on three separate occasions on the Sabbath before Passover, in 1603, 1607, and 1611. Serero adopted and applied arguments from the traditional Sephardic polemics literature but adapted, edited, and expanded these arguments to shape the most appropriate argument.
\end{abstract}

KEY WORDS R. Shaul Serero; Fes; Morocco; seventeenth century; Jewish-Christian Disputation; polemics literature; Jewish philosophy; sermons

\section{Preface}

Medieval Jewish anti-Christian polemical essays written in Christian countries served, inter alia, as a defense against missionary activity. ${ }^{1}$ In Spain, for example, the Jewish-Christian debate was a large part of Jewish

1 Much research literature has been devoted to the Jewish-Christian debate. Some of this literature will be mentioned in its relevant context within this paper. 
life, ${ }^{2}$ which resulted in an abundance of anti-Christian literature. ${ }^{3}$ After the expulsion from Spain in 1492, the ex-conversos continued to compose antiChristian polemical literature in the Christian countries where they had found refuge in order to refute the claims of Christians who tried to prevent them from returning to Judaism (Cooperman 1987; Melnick 1981; Kaplan 1980, 1982, 204-229).

The situation was somewhat different in Islamic countries. Although Christianity was not a threat in the full sense of the term as in Christian countries, the presence of a Christian minority that had existed in Islamic countries from the early days of the Middle Ages and diplomatic and commercial ties between Islamic countries and Christian countries that had deepened over the years led to the fact that the Jews in Islamic countries had to deal with Christianity as well. ${ }^{4}$ This can be seen from the anti-Christian polemic literature composed by Jews from Muslim countries (Lasker 1990; Stroumsa 1997), such as an essay by Dāwūd ibn Marwān al-Muqammiṣ (Stroumsa 1989), and the anonymous Account of the Disputation of the Priest, known in Hebrew as Sefer Nestor ha-Komer (Lasker and Stroumsa 1996). Other Jewish authors in Islamic countries

2 Besides the famous public disputations between official representatives of both religions that took place in Barcelona (1263) and Tortosa (1413-1414), other unofficial and sometimes spontaneous polemical debates involving quasi-educated and 'simple' folk, such as The Majorca Disputation (1286), took place as well (Limor 2003, 2010; Ben Shalom 2003).

3 Such as: Nahman (1963); Profiat Duran (1981a+b); Ben Zemah Duran (1975); Crescas (2002)

4 In fact, some of the members of the Moroccan Jewish community in the seventeenth century, namely in the geographical area and the time period to which this research is devoted, had very significant diplomatic and commercial relations with Christian countries such as Spain, Portugal, Holland, and England. They travelled between these countries in their official roles, cultivating relationships, and some even chose to convert to Christianity in order to improve their chances of success (Garcia-Arenal and Wiegers 2003, 14-20, 32-52). 
argued against Christian doctrine in the course of their discussions of related theological issues such as God's unity or the eternity of the Torah. This approach is frequently found in the philosophical and exegetical works by R. Sa'adia Ga'on (Wolfson 1975, 1997; Lasker 1994). Many others, such as R. Judah Halevi (Schwartz 1994; Lasker 1990) and Maimonides (Lasker 2010), polemicized against Christianity only incidentally.

In other words, despite the fact that Jews in Islamic countries were less threatened by Christian missionary activity, they still felt a need to respond to Christian doctrines on theological grounds and included not only antiChristian passages in their works but also composed complete polemical treatises.

Research on the Jewish-Christian disputations in Morocco, including on Jewish anti-Christian writings, is extremely sparse. ${ }^{5}$ In this paper, I would like to shed more light upon the Jewish-Christian polemic in Morocco and show how it continued until the end of medieval times and the beginning of the Early Modern period. ${ }^{6}$

5 Two main occurrences pertaining to the Jewish-Christian disputation in Morocco are mentioned in research. The first is the disputation that took place in the city of Ceuta in 1179, where the protagonist was a merchant named Guglielmo Alfachino (Limor 1994). The second is the "Marrakesh Dialogues", an anti-Christian text written in Spanish depicting the protracted oral dispute between a friar and a Jewish proselyte. Wilke identified the anonymous author as Estevao Dias, a Portuguese New-Christian who returned to Judaism. Dias penned the first draft of the essay in Marrakesh in or around 1581 and completed it in Antwerp in 1583 (Wilke 2014). On the role of first-person narratives in the discourse of religious polemics, see Szpiech (2013).

6 Research literature disagrees whether the term "Early Modern Period" can be applied to Jewish history; namely, whether the sixteenth and seventeenth centuries are indeed unique in Jewish history. There are those who maintain that unique, significant changes occurred among Jewish People and therefore the period should be defined as a new era, the Early Modern Period. Others claim that the changes during the era were minor and not revolutionary, and therefore do not merit a definition or name different to the period preceding them (Hacker 2015). It is not my intention to come to any conclusion on the issue concerning the Moroccan Jewish community, but it should be noted that some 
After the expulsion from Spain in 1492, between twenty and forty thousand exiles arrived in the Maghreb. Most of them chose to dwell in Morocco rather than in other Maghreb countries; some stayed a short time only (Abitbol 1992). The exiles settled all over the country with a large proportion settling in Fes, which was then the main city both politically and financially, and were favorably received by the sultan, Mulay Muhammad al-Shaykh (Ben Shlomo 1979).

The exiles, known as the Sephardim (from the Hebrew word Səfarad, meaning Spain), fast became acclimatized but founded communities separate from the local Jews, the tošavim (Corcos 1977; Bentov 1986). Over the years, the Sephardim became the dominant community and forced their customs upon the original residents. ${ }^{7}$

R. Shaul Serero (1566-1655), a descendant of Jews expelled from Spain who chose to resettle in Fes, served as the community rabbi during the first half of the seventeenth century (Ohana 2014). In this study, I will examine how he turned to anti-Christian polemic writing, as did his ancestors before him and his peers in Christian countries. ${ }^{8}$

As part of his role as Chief Rabbi, Serero delivered sermons on the Sabbath, holy days, and special occasions. ${ }^{9}$ His sermons were subsequently published (Serero 1989). A study of Serero's sermons shows that he found it necessary to discuss and refute Christian dogma on three separate occasions on Šabbat ha-Gadol, the Sabbath before Passover, in 1603,

scholars of Morocco recognize the beginnings of the modern era in Morocco in the last third of the sixteenth century, as implied by Garcia-Arenal (2008).

7 Yet not without conflict with the tošavim, who wished to preserve their traditions (Gerber 1980, 113-120).

8 The present research is a deeper and broader study of a chapter in my PhD thesis dealing with Jewish-Christian polemics in Serero's sermons (Ohana 2014, 246-251).

9 About the role of the sermon in Jewish communities, see Saperstein (1989), Horowitz (1992), Dan (1996), Regev (2010, 9-38). 
1607, and 1611. Due to their closeness to Passover-the Jewish Festival of Redemption-the sermons delivered by Serero at this time of year were always devoted to the subject of redemption, which was one of the main issues in the Jewish-Christian disputation. ${ }^{10}$

Likewise, it may be suggested that Serero deemed it correct to argue with the fundementals of Christianity around Passover due to its proximity to Easter, the Christian festival commemorating Jesus' resurrection, a time of rivalry and tension between the two religions. ${ }^{11}$

On the first occasion, in 1603 , Serero noted that he felt the need to discuss a certain viewpoint concerning belief in redemption due to an argument posed by a Christian. From here it can be deduced that a religious debate actually occurred. On the other two occasions, in 1607 and 1611, Serero did not state explicitly whether there had been any discussion with a Christian, and it is very possible that in these instances his polemics against Christianity were purely theological and theoretically based.

Therefore, it seems that Serero felt the need to refute Christian dogma both on the grounds of an actual disputation that had taken place in Fes, and on the grounds of the general theological-theoretical perspective that was characteristic of many medieval rabbis in Muslim countries.

Before examining these three cases, I would like to draw attention to an extraordinary event, a public debate between Jews and Christians which

10 With special reference to the question of the Messiah's identity (Lasker 1999).

11 Yuval suggests that the content of the Passover Haggadah evolved while attempting to address the challenges posed by the Christian interpretation of the holiday: the compilers made a conscious effort to emphasize the validity of the Jewish interpretation while rejecting its alternative Christian explanation (Yuval 1996). It should also be noted that in the New Testament the Sabbath after the crucifixion, i.e. the Sabbath after Passover, was Šabat ha-Gadol. In fact, notes Yuval, even according to Jewish tradition Šabat haGadol had been observed on the Sabbath after Passover and was only later changed to the Sabbath preceding the holiday (Yuval 1994). 
took place in Fes twenty years before Serero began to serve as Chief Rabbi. It can be assumed that Serero, who was not yet serving in any official position but was part of the city's rabbinic cadre was somewhat affected by the debate.

\section{The Jewish Community in Fes and Portuguese Captives}

During the fifteenth century, Portugal occupied parts of coastal Morocco and established several fortified outposts along the Moroccan Atlantic coast. Consequently, the 1530 s and the 1540s saw an increase in missionary activity, and religious debates between Franciscan and Jesuit monks and the Jews of Fes, Tetuán and Ceuta took place (Hirschberg 1965, 324; Bashan 1980, 60; Huss 2000, 6-7).

In 1578, King Don Sebastian of Portugal embarked on an unsuccessful crusade after Abū 'Abdallāh Muḥammad II, the deposed Moroccan Sultan, asked him to help recover his throne. ${ }^{12}$ Don Sebastian was accompanied by Jeronimo de Mendonca, a Portuguese chronicler. De Mendonca was taken prisoner by the Moroccan army together with Portuguese soldiers and officers. Upon his release and his return to his homeland, he described the hardships of war and his days of captivity in Fes (de Mendonca 1607). ${ }^{13}$

12 In the Battle of al-Qașr al-Kabīr, the Portuguese army suffered an overwhelming defeat, King Sebastian lost his life, and Portugal lost its independence for sixty years. Two contenders for the Moroccan crown, Abū 'Abdallāh Muḥammad II and Mulay 'Abd al-Mālik, also lost their lives. Hence the event became known as the "Battle of the Three Kings", and Aḥmad al-Manșūr became the king of Morocco (Yahya 1981, 66-91; Garcia-Arenal 2008, 6-39).

13 For de Mendonca's description of the Jewish community in Fes, see Lipiner (1982). 
As part of their incarceration, de Mendonca and the other captives were sent by the Moroccan authorities to stay in the Mellah, the Jewish quarter of Fes. ${ }^{14}$ De Mendonca devoted several pages to describing the mostly positive care that the captives received from the local Jews who were themselves descendants of Spanish refugees: "They [the Portuguese captives] find cure and comfort, as they received very humane treatment from their [Jewish] masters, in addition to the great relief they felt, due to the language usually spoken by the Jews, Castilian" (de Mendonca 1607, vol. 2, 41). ${ }^{15}$ De Mendonca also noted the kindness of the Jewish women, "their gentleness and compassion towards the prisoners, that I was witness to in many cases, and the help that they gave during hours of crisis and sickness" (ibid.). ${ }^{16}$

Ironically, the Portuguese captives sought to thank the Jews who had treated them so well by trying to redeem their souls through missionary activity. ${ }^{17}$ De Mendonca describes the sermons delivered by a priest, Vicente da Fonseca, and the positive reactions that they elicited from the Jews:

14 The Jewish quarter was the area designated to receive all non-Muslim visitors to the city, including Christian travelers, ambassadors, commercial agents, and captives (GarciaArenal 2009, 71).

15 All translations are my own, unless otherwise stated. I would like to thank Mr. Daniel Safran for his kind help in translating the passages from the original Portuguese texts.

16 A description of this sort of kindness was also mentioned by R. Immanuel Aboab, "Those miserables could not find a greater comfort than being sold to the Jews [of Fes] as slaves, as they knew their natural piety“ (Aboab 1629, 308).

17 From its outset, the aim of the Portuguese conquest was missionary and the Jews of Morocco were aware of this. Therefore the date of Don Sebastian's defeat and Morocco's victory, together with the Jewish community's salvation from possible destruction, was designated as a holiday for all future generations. This holiday has since been known as Purim de los Christianos (Nizri 2014, chapter 3). In Jewish communities in the Diaspora it is customary to establish special holidays to commemorate a miracle of salvation and to call them Purim. 
He quoted [in his sermons] the Holy Scripture and the words of the prophets... as they appear in Hebrew. About twenty or thirty rabbis attended his gatherings ... which were held at Don Francisco Portugal [residence]... who was staying in the Jewish quarter... Vicente delivered many sermons during our short stay in Fes, causing many Jews to abandon their religion and convert to Christianity. (de Mendonca, vol. 2, 40) ${ }^{18}$

According to de Mendonca, most of da Fonseca's activities were devoted to "confusing the Jews", therefore he quoted in Hebrew from the Bible. His ability to quote in Hebrew was neither unusual nor surprising, since knowledge of Hebrew among Christian scholars was common from the Renaissance of the twelfth century onward and was part of the Christian Hebraism which sought knowledge of ancient and foreign languages (Benson and Constable 1982, XXIX-XXX). Moreover, during the thirteenth century schools for the study of Arabic and Hebrew were established in some Spanish cities by Mendicant monks so that their graduates could serve as missionaries and preachers in North Africa and Spain (Bischoff 1961).

If de Mendonca's description precisely reflects the priest's arguments without adding nor subtracting from them, it should be noted that da Fonseca quoted only from the Bible and did not deliberate through quotes from the Talmud; this was an early method of deliberation. The twelfth century brought a change in the modes of debate, which until then had concentrated only on biblical texts; Christian scholars now began to familiarize themselves with another holy text, one that pertained to the Jewish way of life, the Talmud. From this time onwards, religious debate revolved around post-biblical literature (Funkenstein 1993). This trend

18 Many of the unofficial disputations took place in private homes (Ben-Shalom 2003). 
increased during the thirteenth century together with the Mendicant teachings that called to approximate the body of knowledge in post-biblical literature and in the original language (Cohen 1982, 1999; Chazan 1989).

De Mendonca noted that the Jews fulfilled their duty of politely listening to the priest, and with the conclusion of the sermon the rabbi of the community responded to his arguments. According to his account the rabbi repeated some of the arguments in a more moderate version, thus infuriating some of the Jews who called him a Christian. From de Mendonca's account it can be seen that there were members of the audience who had wanted to answer the priest and even posed their own difficult questions, but the priest refrained from answering them in order not to be drawn into an uproar and referred only to remarks made by the Chief Rabbi.

Although de Mendonca's descriptions are biased and unobjective, even a minimal interpretation of his report still testifies to the existence of dialogue-even a profound theological debate-between Christians and Jews in the last third of the sixteenth century. ${ }^{19}$ This was a debate through which Christians sought to proselytize, even without any means of coercion, while Jews sought to refute Christianity and prove the basis of their Jewish belief.

It should be noted that in a chronicle written by R. Samuel Ibn Danan III during the same period, he described the defeat of the Portuguese King and the relief felt by the Moroccan Jews but did not mention interfaith debates between the Jews and the Portuguese prisoners. ${ }^{20}$

19 The presence of Portugese captives in Marrakesh, and the decision of some of them to stay there even after their release, brought on the awakening of a religious debate there as well. Those debates are the historical and social background of the "Marrakesh Dialogues" (Wilke 2014, 42-52).

20 After settling in Fes following the expulsion from Spain, members of the Ibn Danan family had a custom where they would write the chronicles of their times and commanded the following generations to continue the practice. R. Shmuel ibn Danan IV collected the 
As already mentioned, Serero did not hold any official position at the time and the event is not mentioned post-factum in any of his sermons or his historical chronicles, but it can be assumed that the disputation was familiar to him.

\section{Three Cases of Šabat ha-Gadol Sermons}

\section{Episode I: Šabat ha-Gadol Sermon of 1603}

Twenty years later, at the onset of the seventeenth century, Serero was appointed Chief Rabbi of the community. By that time the Portuguese captives were no longer a threat, since they had already returned to their homeland. Now the Jewish-Christian debate in Fes revealed itself anew when a Jew who had converted to Christianity ${ }^{21}$ questioned the fundamental tenets of the Jewish faith. ${ }^{22}$

In his Šabat ha-Gadol sermon in 1603, Serero mentioned that two weeks previously he had debated with a Christian: "Fifteen days previous to this sermon, I was part of a debate with a Christian of our seed, and I

various chronicles, including that of R. ibn Danan III, and compiled a single collection. This collection was later published in a critical edition (Benayahu 1993).

21 Throughout the sixteenth century many New Christians - formerly Jews and Muslims chose to settle in North Africa in the hope of escaping from the eyes of the Church and returning to their original religions (Hirschberg 1965, 322-324; Beinart 1998, 855-868; Garcia-Arenal and Wiegers 2003, 39-41).

22 During the Middle Ages it was common for Jewish apostates to participate in JewishChristian disputations and even lead them (Cohen, 1987). Yet as mentioned above, most of the New Christians in Fes returned to their roots, and thus positive, mutual relationships were formed between the Jews of Fes and the ex-conversos. 
have prepared this sermon about what he asked me and what I answered him" (Serero 1989, vol. 1, 113). ${ }^{23}$

The Christian raised two arguments against the Jewish belief of redemption: a) regarding the length of the exile: the prolonged duration of the exile discouraging the expectation of salvation; b) regarding the quality of the exile: the dispersion of the Jewish People in many lands is even more hopeless. According to the apostate, if the Jewish People had all been exiled to one place, a gradual amassing of strength and cooperation could possibly lead to the success of a natural national uprising, but the dispersion among nations the world overnegates such a possibility.

Indeed, the continuing Jewish exile had been an ongoing subject in Christian debate since the time of Aurelius Augustinus (354-430), who held that the Jewish exile was proof of the truth of Christianity. This claim was typical of the historical arguments used in religious debates since reality was considered ordained by God. ${ }^{24}$ The Christians claimed that the Jewish exile proved that God transferred his choice from "Israel of the flesh" to "Israel Spiritualis". In other words, the Jews' existence as a despised, humiliated minority is allegedly evidence both of their mistake and of God's rejection and at the same time validates Christianity.

23 The terminology used by Serero "Christian from our seed" can be interpreted in two senses: as a direct convert or as a converso. In any event, it should be noted that throughout his sermon, Serero calls him "Christian" and not "Jewish convert": "These are the words of the Christian", "And this is what the Christian claimed", "And thus we have explained the two allegations that the Christian brought as proof", "And this was my answer to the Christian".

24 However, it should be noted that Lasker claims that historical allegations were not extremely forceful-compared with exegetical and rational arguments-since both sides interpreted what they perceived in accordance with their preconceived doctrines (Lasker 1977, 7-9), as indeed did Serero (see below). 
Moreover, the matter of exile was one that touched the core of medieval Jewry and was an issue with which Jews wrestled between themselves, irrespective of their debates with Christians. ${ }^{25}$

In the above-mentioned case, the question was not the classic difficulty of the "length of exile", since the Christian did not claim that the Jews' exile was proof of their mistake or of God's abandoning them, nor did he wonder why their punishment (the exile) was so long. The apostate claimed that such a long exile and the wide dispersion of the Jewish People were the cause of Jews' despair concerning their redemption. In other words, the characteristics of the exile are the cause of doubt with reference to the probability of redemption.

Therefore, if this Christian was a direct convert it would seem that his Jewish past enabled him to pinpoint the concerns of Jews living at the end of the Middle Ages and perhaps reflected his innermost thoughts; but if he was a converso it is possible that the continuing exile, and perhaps the difficult circumstances of the Jews in Fes from the end of the sixteenth century and throughout the seventeenth century, ${ }^{26}$ deterred him from returning to Judaism despite his original intention to do so when he left Spain or Portugal. ${ }^{27}$

25 Rosenberg points out eight explanations clarifying the reasons for the Jews' dispersion: a) a punishment; b) representing the "messianic birth-pangs“; c) the Land of Israel's "vomiting" the sinners who dwell within (Leviticus 18:28); d) the consequence of certain astrological conditions; e) a mission; f) a "Tiqun“ (from a Kabbalistic aspect); g) the result of the fundamental ontological structure of the world; h) sin (Rosenberg 1983).

26 For details about the difficult circumstances that prevailed in Fes during those years, see Garcia-Arenal and Wiegers (2003, 27-32); Serero (1989, vol. 1,128, 155: vol. 2, 46, 189); Benayahu (1993, 71-90). Serero notes the difficulties facing the community: repeated wars, heavy taxes, famine, and the dangers lurking on highways. As a result, he states, some even chose to convert to Islam. Regarding the history of Moroccan Jews converting to Islam, see Garcia-Arenal (1987).

27 In a sermon two years previously, in 1601, Serero noted that Jews who had converted to Christianity immigrated to Fes in order to return to Judaism, but once they realized the 
Serero shared (with his congregants and his future readers) the method that he thought most correct to answer the apostate's claims. He noted that he did not think it fitting to answer that the future redemption would be supernatural, and therefore natural or geopolitical difficulties would not prevent its occurrence. ${ }^{28}$ He noted that he had decided to answer the Christian in the same manner: demonstrating that the length and quality of the exile are actually proof of God's providence and therefore reinforce Jewish belief in the redemption (Serero 1989, vol. 1, 113).

This type of argument was common among medieval debaters: the speaker would accept his opponent's basic premise and then prove the weakness of his arguments (Talmge 1981, XVI).

Serero claimed that the extended exile proved God's providence from two angles:

a) The actual existence of the Jewish People, despite their long exile and suffering, is evidence of providence since the Jews would otherwise have been eradicated long ago. This argument was also often used by Jews among themselves to explain the length of their exile (Rosenberg 1983, 404). Serero referred to Talmudic sages (in BT, Sota 9a) who claimed that the exile is ongoing since God, in his infinite mercy and providence, does not punish the Jewish People at one time but extends the retribution throughout the generations.

b) In spite of the length of the exile, the Jewish People remain strong in their belief of God, and perhaps even grew stronger; if not for Divine Providence, it would be impossible for humans to continue to believe throughout such a long exile.

poor conditions under which the Jews of Fes were forced to live they preferred to return to their homelands and adhere to their new religion (Serero, 1989, vol. 1, 71).

28 For more about Serero's understanding of redemption, see Ohana (2014, 235-256). 
The quality of the exile-namely the wide dispersion of the Jews-is also proof of Divine Providence: God found it necessary to disperse the Jews so that if non-Jews were to destroy a Jewish community in a certain place, there would still be another community elsewhere. Therefore, the sages explained the verse "righteous deeds towards the inhabitants of his villages in Israel" (Judges 5:11) as "God has done righteously with the People of Israel in His dispersion of them amongst the nations" (BT, Pəsaḱim 87b, Serero 1989, vol. 1, 123).

If so, Serero offered an alternative explanation to the historical reality, which is more suitable to Jewish belief, thus refuting the Christian's claim.

Historical arguments were often supported by references from the Scriptures, ${ }^{29}$ and Serero continued in this line throughout his sermon. Serero states that both arguments presented by the apostate were mentioned in the book of Leviticus. Regarding the dispersion among the nations, it is written "I will scatter you amongst the nations" (Leviticus 26:33), while "you shall perish among the heathens" (38) points to the length of the exile. Yet immediately after mentioning the terrible fate to befall His people, God promised two kind of protection: “But despite all this, I will not utterly reject or despise them while they are in exile in the land of their enemies..." (44), thus ensuring the Jews' physical existence, and "I will not cancel my covenant with them by wiping them out, for I am the Lord their God" (ibid.), concerning their faith and belief.

Serero continued at length, adding verses from the Bible and sayings of Talmudic sages to support and explain his argument. However, as stated above this debate was with a Christian, and Serero felt it necessary to bring up the arguments posed by the contender and his own answers in a sermon

29 In fact, exegetical arguments from the Hebrew Bible were the most prevalent in JewishChristian polemics (Lasker 1977, 3-7). 
delivered shortly thereafter. Thus the above-mentioned documentation, the written sermon, is not a record of the original debate but of the oral sermon delivered thereafter. Moreover, it is likely that some changes were made when the sermon was later put in writing (Dan 1975, 35-36; Saperstein 1989, 7-9, 2-24). Therefore it is very possible that only some of the manifold sources mentioned in the written version were included in the oral sermon or in the original debate.

Nevertheless, the main points are valid, and an unofficial JewishChristian debate actually took place in Fes at the beginning of the seventeenth century. The debate centered on the issue of exile and redemption of Israel, one of the most common subjects of ChristianJewish polemics. The argument that the long duration of the exile and the wide dispersion of the Jewish People were proof of God's providence was often used by medieval Jews to explain the exile to themselves. It seems that Serero developed this argument and used it further: he claimed that God's providence as perceived in the diaspora not only explains and offers comfort for the hardships of the Jewish exile but is also a guarantee of future redemption.

\section{Episode II: Šabat ha-Gadol Sermon of 1607}

Four years later, in his sermon on Šabat ha-Gadol of 1607, Serero argued that every Jew must believe in the future arrival of the Messiah. He added that although R. Joseph Albo (1380-1444) maintained that this belief is not one of the three main fundamentals of Jewish belief (God's existence; revelation; divine justice), and those contradicting the concept were 
not considered heretics, ${ }^{30}$ each and every Jew must believe it since it is “acknowledged by us, passed down to each generation, [originating] from the prophets who prophesized it" (Serero 1989, vol. 1, 182).

At this point Serero raised the question whether this tradition is reliable and trustworthy, since the Christian tradition claims that the Messiah has already arrived.

The Christian claim, opposing the Jewish belief that the Messiah has not yet arrived, was one of the fundamental arguments in medieval interfaith debates ${ }^{31}$ and was even the subject of the polemical essay by Johan Harrison, an English diplomatic agent, written as a result of his stay in Morocco during the first third of the seventeenth century (Harrison 1612; Garcia-Arenal and Wiegers 2003, 75).

Serero refuted the Christian argument by questioning the entire Christian tradition: for if the Christian tradition is altogether faulty, he argued, then their tradition regarding the Messiah is also unreliable. Therefore, he had to determine whether the Christian or Jewish tradition was more credible, and whether a tradition is a reliable source at all: "Firstly we must clarify that tradition is most appropriate and most committed to the belief of each and every believing person" (Serero 1989, vol. 1, 183).

Serero's proof that a tradition which has been handed down throughout the generations is, in principle, a reliable source of information for the religious person consists of two arguments and was influenced by medieval

30 In addition to the three fundamental principles of divine Law, Albo posits "root principles" (šorašim) that are derived from them. From the "root" principles, Albo proceeds to derive "branch principles" ('anafim). These are principles in which everyone adhering to Mosaic Law is obligated to believe, although one can practice Divine Law in general, and particularly Mosaic Law, without any of them (Kellner 1986, 140-151).

31 This, for example, was the first subject discussed in the Barcelona Disputation. 
Jewish philosophical discourse on the subject, especially that of R. Joseph Albo (Albo 1946, 19; Lasker 1980):

a) This is similar to one who, based on his senses, recognizes the probable occurrence of a phenomenon even though such an occurrence seems theoretically impossible. This argument is based on the assumption that experience is prior to intellect, meaning that historical occurrences undermine doubt based on the theory of natural law-all the more so when many people were witness to the occurrence. ${ }^{32}$

b) When a certain generation witnesses a historical event, the members of that generation retell the story to their children and grandchildren who, in turn, continue to relate it to their offspring and so forth. The narration is reliable since fathers would not lie to their sons.

Therefore, the direct verification based on the first generation's senses (argument a) and the reliability of the testimony handed down from father to son (argument b) testify to the reliability of the tradition for the following generations, as though they were personally witness to the occurrence. ${ }^{33}$

Similarly, Serero believed that both the recipient (the son) and the bestower (the father) must verify the validity of the tradition. The recipient must ensure that he heard everything correctly, as is written "We have heard with our ears, Oh God" (Psalms 44:2), while the person passing on the tradition must fulfill two other conditions: a) he must ensure that he did

32 R. Yehuda Halevi had already formulated this perception while confronting the philosophers' denial of the possibility of prophesy. He claimed that the actual occurrence of prophesy at Mt. Sinai refutes the philosophers' denial (Kreisel 2001, 100).

33 R. Saadia Gaon had already claimed that reliable tradition was parallel in its credibility to sensory perception, "authentic tradition is as trustworthy as things perceived with our own eyes" (Saadia Gaon 1948, 157). R. Yehuda Halevi stated, "I and the rest of the Jewish people are obliged to believe based on our first-hand encounter with God [at Mount Sinai]. We have passed down this account, without interruption, from generation to generation, and so even today it is as if we are eyewitnesses to the event" (Halevi 1998, 14-15). 
not want to lie to the recipient-in this case, since the parents are passing on tradition to their own children, there should be no fear of this happening, "our ancestors tell us" (ibid.); b) he must ensure that the source of the tradition are those people who witnessed the occurrence themselves, as it is written "what work you did in their days" (ibid.).

If this were so, Serero had proven that a tradition is, in principle, a trusted source. At this point we can return to the matter at hand: Which is the reliable tradition concerning the arrival of the Messiah? The Jewish tradition that maintains that he has not yet arrived and is yet to come, or the Christian tradition that holds that he has already appeared? As I have already mentioned, Serero chose to discredit the entire Christian tradition and therefore its claim to the coming of the Messiah as well. ${ }^{34}$

He raised two arguments: the first, using a technique often utilized by medieval debaters, was based on a historical overview of the chain of events in Jesus' time. ${ }^{35}$ Serero points out that Jesus was one single person who tended to disagree with the majority of his contemporaries, appointed

34 As already stated, Serero was very much influenced by Albo's discussion of the issue of the credibility of a tradition but did not use his argument in the issue at hand, namely how one can know which tradition is the true one and which is not (although he did mention Albo's argument under different circumstances). Albo lays down two areas of investigation: a) an examination of the law itself, meaning that Divine Law must contain all the fundamental and root principles by virtue of which it exists; b) an examination of the messenger (prophet), either directly (essentially) or indirectly (Albo 1929, vol. I, chapter 18). Likewise, Serero did not use Albo's argument that Christianity should be rejected since it is based on impossible logic, while the Jewish faith is based on natural impossibility (vol. III, chapter 25; Lasker 1980).

35 From the early Middle Ages onwards, Jews who were interested had access to essays dealing with Jesus and the history of Christianity, such as Sefer Tolədot Yeshu (The Life of Jesus). In fact, historical essays describing Jewish history together with world history, such as R. Avraham Zechut's Sefer Yuhasin, were written, inter alia, as a tool for use in inter-religious disputations against Christianity (Ben Shalom 1994). Furthermore, even Christian Historiography was available to the Jews of Spain and Provence in the Middle Ages (Ben Shalom 2006). 
himself Messiah, and called himself the son of God. All rabbinic leaders of the time disagreed with Jesus' claim, and since he continued to hold by it he was sentenced to death. After his death, a few people in every generation continued to follow his teachings.

Similar to other Medieval Jewish debaters, Serero did not refute the details of the event but offered another meaning. Like others before him, he changed the Christological understanding of crucifixion, arguing that since Jesus rebelled he deserved the death penalty. ${ }^{36}$

Serero points out that Christian tradition is based on the evidence of a single person who deviated from the mainstream, while Jewish tradition is based on the evidence of many. ${ }^{37} \mathrm{He}$ added that Christians admit that their religion began with a small number of followers, and that this is even documented in the Christian Gospel. It should be noted that through this use of Christian literature, Serero takes advantage of his opponent's sources and explains them in a manner different to their original intent. ${ }^{38}$ He added that in spite of the Christians being larger in number than Jews in his day, this was not any kind of proof but the earliest days of Christianity. In other words, according to Serero, since the Christian tradition is based on the testimony of a single man who deviated from the majority, it can be rejected.

Serero continued by stating that Jesus' disciples claimed that he also wrought miracles; however, he argues that those miracles do not obligate belief in him. In order to explain why, Serero used an exegetic argument:

36 For example, "Every thing which the Jews did to him was good and just according to Your word, since they did His will“ (Lasker and Stroumsa 1996, vol. I, 102).

37 This argument echoes Rabbi Yehuda HaLevi, who discussed the 600,000 witnesses at the giving of the Torah at Mount Sinai (Yehuda Halevi 1988, 1, 88).

38 Amos Funkenstein defined this as "counter history" and pointed out its existence in polemic literature (Funkenstein 1992). 
1) Jesus proclaimed himself God's son and even contradicted Jewish commandments, but according to Deuteronomy 13: 2-6, one should not listen to a prophet who wishes to sway the Jewish People from worshipping [the one] God to worshipping "other gods", even if he does perform miracles, since there is a possibility that the miracles were wrought through a spell or impure forces. Therefore miracles are not an indication that their performer is indeed a true prophet.

It must be pointed out that medieval Jewish theologists recognized the occurrence of miracles wrought by Christian holy men through impure powers and spirits (Galinsky 2011). Moreover, Kabbalists from the generation of the Spanish expulsion onwards had a demonological perception of Christianity, whereby Jesus himself was the incarnation of Samael (Gross 1993). Serero also held this position, and on Šabat haGadol in 1612 he preached, “...and here all the paramount impure forces of impurity attached to Lilith and Samael materialized and became one, embodied as Jesus" (Serero 1989, vol. 1, 263).

2) Serero raised the possibility that there are those who may claim that the above-mentioned verse (Deuteronomy 13: 2-6) is applicable only against those who try to influence Jews to worship other gods, and therefore is not applicable to Jesus, who only claimed to be the Son of God. Serero replied that the concept that Jesus was the son of God transforms Jesus himself into a god (and not only a Messiah), since God is one; hence the Father and the Son are one and the same. Consequently, the Christian concept that Jesus is the Son of God classified Christianity as idolatry.

The debate over the Trinity was a central feature of almost every Jewish anti-Christian polemical work. According to Christian doctrine, there is one God with three personifications: the Father, the Son and the Holy Spirit; each personification is God: still there is only one God. 
By contrast, Jewish polemicists claimed that if the Father is God, and the Son is God as well, it would seem that the Father and the Son are one and the same, based on the logical ruling that two things that are identical with the third will also be identical to each other. Therefore the Christians' claim that it is possible to discern between the Father and the Son is incoherent. Therefore, a large number of Jewish polemicists rejected the Trinity doctrine since syllogistic logic refuted it (Lasker 1977, 90-93).

A careful reading of Serero's argument shows that he used this syllogism concerning the identity of the Father and the Son but did not refute the doctrine of the Trinity through logical argument, as did others. Serero pointed out that according to this view Jesus is God, and therefore Christianity must be defined as idolatry. Consequently, the miracles that Jesus wrought do not require one to believe in him since according to Deuteronomy (13: 2-6) one should not believe a prophet who tries to sway Jews to idolatry, even if he possesses the ability to perform wonders.

The second argument that Serero raised in undermining the credibility of Christian tradition deals with Christianity's annulment of divine commandments. The debate concerning the Christians' annulment of commandments was extremely stormy during the Middle Ages. Jewish polemicists raised the argument that the annulment of the commandments would have been foreign to Jesus himself, ${ }^{39}$ thus emphasizing the changes initiated by Paul the Apostle. They tried to demonstrate that latter-day Christianity was unfaithful to its own sacred writings and hence had no validity even for the Christian, let alone the Jew (Schwartz 1994, 3).

39 To that, R. Profiat Duran dedicated the fourth chapter of his book The Reproach of the Gentiles. As a result of this distinction between the original intention of Jesus and the subsequent church leaders, Duran and other Jewish thinkers argued that the history of early Christianity should be divided into two stages (Ben Shalom 2006, 154- 174). 
Serero also mentions the gradual phasing out of commandments and notes that three hundred years after Jesus' death there were still Christians who observed the commandment of circumcision-until the pope ordered its annulment. Gradually, generation by generation, Christianity annulled commandments originating in the Pentateuch, until it eventually dismissed them all, claiming that the obligation to fulfill them was valid only until the time of Christ; from then onwards a new doctrine reigned.

However, it seems that for Serero the essence was not the radical departure from Jesus' intentions (hence the necessity for proof vis-à-vis the lack of the credibility of the Christian doctrine but the abolishment of the commandments themselves. The changes that the Christians wanted to make to the Divine Torah were proof of lack of credibility in Christian doctrine. Serero maintained that the Torah was divine and therefore perfect and eternal, and hence will never change. Moreover, if so many were present in the giving of the Torah, then how it can be argued that an event so public can be nullified in consequence of the testimony of one single person?

In other words, Serero claimed that the Christian tradition as a whole was not credible, hence the claim that the Messiah has already come must be repudiated as well. However, Jewish tradition has proven credible; hence its claim that the Messiah is still to appear remains firm and abiding.

If so, in one of his annual pre-Passover sermons, which were always devoted to the issue of salvation, Serero confronted Christian doctrine and rejected it. Since Serero did not specifically state that this was due to a debate that actually took place, as he did in the first case, it is quite possible that this was simply a theoretical reference to Christianity, but of this we can not be sure. 


\section{Episode III: Šabat ha-Gadol Sermon of 1611}

In his Šabat ha-Gadol sermon in 1611, Serero once again discussed the Christian belief that the Messiah had already come. Unlike the previous sermon, in which he sought to refute the Christian concept of redemption by undermining the credibility of the Christian tradition as a whole, Serero now found it necessary to refute the claim directly, "and according to the Christian argument that Messiah has already come and his promises have been fulfilled ... we will clarify and show that the Messiah has not yet arrived" (Serero 1989, vol. 1, 253).

Serero found it necessary to begin by proving that the Torah hints about belief in the coming of the Messiah in Bilə'am's fourth prophesy (Numbers 24: 15-17). 40 "I see him but not now" (17), suggests the reign of King David; "I behold him, but not near" (ibid.), is a clue to the Melex ha-Mašiah-the King Savior who will appear in the distant future of the end of days. "A star will come out of Jacob" is also a clue to King David's kingdom, while the continuation of the verse, "a scepter shall rise out of Israel", indicates the King Savior. Serero stated that Bilə'am's prophecies were mentioned in the Torah since they would be realized in the future; all came true except for the last. Therefore, one should believe that this last prophecy will still come true.

At the same time, Serero explained that this part of the Book of Numbers describes the exile of the First Temple and the subsequent redemption, while Deuteronomy $(28: 36 ; 28: 68)$ deals with the present exile

40 Earlier commentators had already interpreted Bilam's prophecy as dealing with the Messiah King. For example, Nahmanides (Numbers 24: 19), Abravanel (Numbers 24: 1425), Rabbenu Bahye ben Asher (Numbers 24: 18), R. Avraham Saba (Numbers 24: 17), R. Moshe Alsheikh (Numbers 24: 15). 
and redemption. Although the end of days is not explicitly mentioned in the admonitions cited in Deuteronomy, ${ }^{41}$ there is a hint to it:

"When all these things come upon you ... and you return to the Lord your God and obey his voice ... and God will restore you from captivity and have compassion for you, and will return and gather you from all the nations amongst whom the Lord your God has scattered you." (Deuteronomy, 30: $1-3)$.

The prophecy continues, "If your outcasts be at the ends of the earth, the Lord your God will take you from there". From here it can be deduced that this text did not allude to Šivat Șiyon-the Return to Zion after the destruction of the First Temple-because God did not gather all members of the Jewish nation from all over, but only from Babylon. Thus, the Torah's allusion is to a future redemption.

Serero then proved that contrary to Christian claims, the redeemer has not yet arrived, as the prophecies describing the era of the redemption did not occur during the time of the Second Temple: "Let us clarify that the redeemer has not yet come, since we have shown that the prophesies have not yet taken place" (Serero 1989, vol. 1, 256).

To mention just a few of Serero's examples: Isaiah's words pertaining to the redemption, "And the sons of strangers shall build your walls and their kings shall minister to you... the nation and the kingdom who shall not serve your will perish" (Isaiah, 60: 10-12), have not yet been realized. Nor have prophesies by Zechariah (14:8), Ezekiel (47:1) and Joel (4:18), pertaining to living water that leaves the holy Temple and Jerusalem. Zephaniah's prophecy about the days of redemption when all of the nations will believe

41 Nahmanides already interpreted it thus in his explanation of Leviticus 26:16. 
in God and "when I will purify the lips [languages] of the nations that they may all call on the name of the Lord and serve him shoulder to shoulder [together]" (Zephaniah, 3:9) has not yet been realized either.

Consequently, rules Serero, the redemption and the redeemer have not yet arrived, and therefore these prophesies will be realized at the time of the future redemption. The unfulfilled state of these prophecies indicates that the redemption had not yet occurred; hence the Christian claim of the appearance of the Messiah is an explicit contradiction to scripture.

This kind of rejection of Christian dogma regarding the Messiah was common in Jewish anti-Christian writings. For example, R. Sa'adia Ga'on's perception of redemption as apocalyptic refutes the Christian claim that the redemption occurred during Jesus' time and that Jesus was the Messiah, as all of the miracles that go together with the concept of the redemption as apocalyptic were not realized, and nature still stands as firmly as before (Sa'adia Ga'on 1948, III, 7-8).42 Years later, even those who held that the future redemption would be naturalistic adopted this argument, suiting it to their school of thought. Since no far-reaching social or political changes occurred with Jesus' appearance, they argued, he could not be classed as the Messiah (Schwartz 2005, 43-44).

If so, Serero utilized a set of arguments from his predecessors. However, he also added a new dimension, a new criterion stemming from the kabbalah. According to the kabbalah, Israel's exile manifests the exile of the Šəxina (the Divine Presence), meaning disconnection and separation of the spheres. However, at the time of the redemption the spheres will reunite (Sack 1980, 1995, 249-266). Accordingly, Serero maintained that

42 R. Hasdai Crescas (1340-1410) also raised this argument claiming that since the destruction of the Kingdom of Israel, the Land of Israel had not been rebuilt, nor had world peace and abounding wisdom and prophecy been realized; it can therefore be deduced that the Messiah has not yet come (Crescas 1990, 77). 
Ezekiel's prophecy_"Therefore saith the God the Lord" (Ezekiel, 39: 25), showing that at the time of redemption the unity of tif'eret and malxut (two of the ten attributes/emanations in the kabbalah) will be complete-did not happen in the Second Temple era.

\section{Conclusion}

Serero's annual sermons on the Sabbath preceding Passover were devoted to clarifying issues connected to the redemption in its various aspects. An overview of his sermons reveals that Serero was motivated not purely by interpretive motives, but that he also responded to religious and philosophical challenges on the subject. To a small extent this echoes the Jewish-Christian debate both in connection with an argument raised by a Christian undermining the Jewish' perception of redemption, and the Christian perception of salvation as a whole, particularly in relation to Jesus as the Messiah.

A review of Serero's sermons concerning Judeo-Christian polemics shows that he continued the Spanish tradition on the subject, ${ }^{43}$ just as he had done in relation to other theological issues. It seems that Serero adopted and applied arguments from an existing, known corpus of polemics but shaped and edited them until he found an explanation that suited him.

It should be noted that his writings were not intended as polemical literature but rather as sermons delivered at regular times each year to uplift and encourage his congregation. The subject of redemption was a permanent one for the pre-Passover sermon, and therefore the rabbis'

43 Lasker claims that very little changed in Jewish-Christian polemics with the transition from the Middle Ages (Lasker 2006). 
intention was to reinforce belief in the future redemption. Apparently, Serero found it necessary to clarify this issue not only in its Jewish context, but with regard to Christian doctrine on the subject as well. If so, the question that may be raised is what historical reality does this sermonizing reflect?

Inasmuch as a work reflects its author's social and cultural context, it would seem that although missionary activity and religious debates were few in Jewish Fes, and Jews were not subject to measures against them after Morocco was liberated from Portugal, religious tension continued to exist. It would seem that when the public had become aware of the conflict between Christianity and Judaism, Serero found it necessary to debate Christian dogma in his public sermons.

Moreover, there were cases of conversion to Christianity among the community of Fez during Serero's lifetime. Such conversions took place due to the extreme distress to which the community was subjected to from time to time, while Christianity enjoyed prosperity and welfare. Both elements led some Jews to doubt the divine providence of God over the Jewish people and consequently led them to convert to Christianity, as Serero testified in a sermon from 1608:

And all the success [of the gentiles] that Israel sees, is a reason [for Israel] to join in their religion [to Christianity] ... they [Israel] see Israel in its misery and therefore they deny the providence of god on Israel ... therefore the peacefulness and success of the gentiles was so astounding to them that it almost drew them away and they were weakened in their belief" (Serero 1989, vol.1, 215, my translation). 


\section{Acknowledgement}

This article is based on a presentation in the workshop Eastern Jews and Christians in Interaction and Exchange in the Islamic World and Beyond: A Comparative View (22-23 June 2016), carried under the auspices of the ERC-funded project JewsEast (grant agreement no. 647467), the Ben-Zvi Institute of the Hebrew University in Jerusalem, and with the Center for the Study of Jewish-Christian-Muslim Relations (JCMCentre) of the Open University in Ra'anana.

\section{Reference List}

Abitbol, Michel. 1992. "Yahadut Șəfon Afriqa 'aḥare Geruš Səfarad."

[North Africa Jews after Spanish expulsion] In ha-Pəzura haYehudit Səfaradit Ahare ha-Geruš mi-Səfarad [The Sephardic Jewish Diaspora after the Expulsion from Spain], edited by Michael Abitbol, Joseph Kaplan, Reuven Bonfil, and Joseph Hacker, 9-26. Jerusalem: The Zalman Shazar Center.

Aboab, Immanuel. 1629. Nomologia o Discursos Legales. Amsterdam. Albo, Joseph. 1929, Sefer ha-'Iqarim (Book of Principles), translated by Isaac Husik. Philadelphia: Jewish Publication Society.

Bashan, Eliezer. 1980. Šəviya u-Pədut ba-Hevra ha-Yəhudit bə'Arsșot ha-Yam ha-Tixon (1391-1830) [Captivity and Ransom in Mediterranean Jewish Society (1391-1830)]. Ramat-Gan: Bar-Ilan University Press.

Beinart, Haim. 1998. Chapters in Judeo-Spanish History, Vol. II. Jerusalem: Magnes Press. 
ben Nahman, Moshe. 1963. "Vikuakh HaRamban." [Account of the Barcelona Disputation] In Kitvei Ramban, edited by C.D. Chavel, 302-320. Jerusalem: Rav Kook Institute.

Ben-Shalom, Ram. 1994. "Historiografia Polmusit bə-Sefer Yuhasin." [Polemic Histography in Sefer Hayokhasin] The 11th Congress for Judaic Studies, Section II, Vol. I., 121-128. Jerusalem.

-_-. 2003. "Between Official and Private Dispute: The Case of Christian Spain and Provence in the Late Middle Ages." AJS Review 271: 23-71.

- - - 2006. Facing Christian Culture - Historical Consciousness and Images of the Past among the Jews of Spain and Southern France during the Middle Ages [in Hebrew]. Jerusalem: Ben-Zvi Institute. Ben Shlomo, Avraham from Torrutiel. 1979. "Sefer ha-Qabala." [The Book of the Kabbalah] In Šətei Xronikot 'Ivriyot mi-Dor Geruš Səfarad [Two Chronicles from the Generation of the Spanish Exile], edited by Avraham David, 38. Jerusalem: The Zalman Shazar Center.

Benayahu Meir, ed. 1993. Divre ha-Yamim šel Fes - Gəzerot u-Mə’ora'ot Yəhude Marocco kə-fi šərašmun Bne Mišpahat ibn Danan ləDorotehem [History of Fes: Misfortunes and Events of Moroccan Jewry as Recorded by ibn Danan's Family and Descendants]. Tel Aviv: Tel Aviv University.

Benson, Robert, L., and Giles Constable, eds. 1982. Renaissance and Renewal in the Twelfth Century. Oxford: Clarendon.

Bentov, Chaim. 1986. “Qəhal ha-Tošavim bə-Fes mə-ha-Me’a ha-16 va'elax." [Residents of Jewish Community in Fes from the 16th Century] East and Maghreb 5: 79-108. 
Ben Zemah Duran, Shimon. 1975. Kešet u-Magen: a critical edition [Bow and Shield], edited by Prosper Murciano. Ann Arbor: Xerox University Microfilms.

Bischoff, Bernhard. 1961. "The Study of Foreign Languages in the Middle Ages." Speculum 36: 209-224.

Chazan, Robert. 1989. Daggers of Faith: Thirteenth-Century Christian Missionizing and Jewish Response. Berkley: University of California Press.

Cohen, Jeremy. 1982. The Friars and the Jews: The Evolution of Medieval Anti-Judaism. Ithaca: Cornell University Press.

_-_. 1987. “The Mentality of the Medieval Jewish Apostate: Peter Alfonsi, Hermann of Cologne, and Pablo Christiani." In Jewish Apostasy in the Modern World, edited by Todd M. Endelman, 2047. New York: Holmes \& Meier.

- - - 1999. Living Letters of the Law: Ideas of the Jews in Medieval Christianity. Berkeley: University of California Press.

Cooperman, Bernard. 1987. “Elijah Montalto's 'Suitable and Incontrovertible Propositions': A Seventeenth-Century AntiChristian Polemic." In Jewish Thought in the Seventeenth Century, edited by Isadore Twersky, and Bernard Septimus, 469-497. Cambridge, MA: Harvard University Press.

Corcos, David. 1977. "The Jews of Morocco from the expulsion of Spain until the middle of the 16th Century." In The Jews in Sharifian Morocco, edited by Shalom Bar-Asher, 116-118, 122127. Jerusalem: The Zalman Shazar Center.

Crescas, Hasdai. 1990. Sefer Bițul 'Emunot ha-Noșrim [The Nullification of The Christian Belief], edited by Daniel Lasker. Ramat Gan, and Beer Sheva: Bar Ilan University Press. 
- - - 2002. Sefer Bițul 'lqare ha-Noșrim [Refutation of the Christian], edited by Daniel J. Lasker. Bar-Ilan University Press and BenGurion University of the Negev Press.

Dan, Joseph.1975. Sifrut ha-Musar ve-Hadəroš [Hebrew Ethical and Homiletical Literature]. Jerusalem: Keter.

———. 1996. “Іə-Bə‘ayat Ma‘amada šel Sifrut ha-dəraš bə-Tarbut Yisra‘el bi-Yəme ha-Benayim u-va-azman ha-Hadaš." [Some Notes on Homiletic Literature in Jewish Medieval and Early Modern Culture] In ha-tarbut ha-'Amamit [Studies in the History of Popular Culture], edited by Benjamin Kedar, 141-153. Jerusalem: The Zalman Shazar Center.

de Mendonca, Jeronimo. 1607. Jornada de Africa. Lisbon.

Funkenstein, Amos. 1992. “Historia, Historia-še-ke-neged və-Siper."

[History, Counter History and Narrative] Alpaim 4: 206-222.

_-_. 1993. Perception on Jewish History. Berkeley: University of California Press.

Galinsky, Judah. 2011. “Gišot Šonot lə-Tofa'at Mofte ha-Qədošim haNoșrim bə-Sifrut ha-Rabanim šel Yeme ha-Benayim." [Different Approaches towards the Miracles of Christian Saints in Medieval Rabbinic Literature] In TA SHMA: Studies in Judaica in Memory of Israel M. Ta-Shma, Vol. I, edited by Avraham Reinar et al., 195219. Alon Shevut: Tevunot Press.

Garcia-Arenal, Mercedes, and Gerard Wiegers. 2003. A Man of Three Worlds: Samuel Pallache, a Moroccan Jew in Catholic and Protestant Europe. Baltimore, MD: Johns Hopkins University Press.

Garcia-Arenal, Mercedes. 1987. “Les bildiyyin de Fes: Un Groupe de Neomusulmans d'origine Juive." Studia Islamica 66: 113-143. 
-- - 2008. Ahmad al-Mansur: The Beginning of Modern Morocco. Oxford: One world Publications.

Gerber, Jane S. 1980. Jewish Society in Fes 1450-1700. Leiden: Brill. Gross, Abraham. 1993. "ha-Satan və-ha-Nașrut: Demonizașia šel haNașrut bə-Xitve 'Avraham Saba." [Satan and Christianity: The Demonization of Christianity in the Writings of Abraham Saba] Zion 581: 91-105.

Hacker, Joseph. 2015. "Is the Early Modern Age a Period in the History of Israel?" In Mile Stones: Essays, A Period in Jewish History, edited by Immanuel Etkes, David Assaf, and Joseph Kaplan, 165-180. Jerusalem: The Zalman Shazar Center for Jewish History.

Halevi, Yehuda. 1998. The Kuzari: In Defense of the Despised Faith, translated by Daniel Korobkin. Northvale: Aronson.

Harrison, Johan. 1612. The Messiah already come or profess of Christianitie... to convince the Jewes, written in Barbarie in the year 1610. Amsterdam.

Hirschberg, Haim. 1965. Tolədot ha-Yəhudim bə-'Afriqa ha-Șəfonit [A History of the Jews in North Africa], vol. 1. Jerusalem: The Bialik Institute.

Horowitz, Carmi. 1992. “'Darshanim', 'Derashot' and the 'Derasha' Literature in Medieval Spain." In The Sephardi Legacy I, edited by Haim Beinart, 383-398. Jerusalem: Magnes Press.

Huss, Boaz. 2000. 'al 'Adane Paz - ha-Qabala šel Rabi Šimon Ibn Lavi [Sockets of Fine Gold - The Kabbalah of Rabbi Shimo'n Ibn Lavi]. Jerusalem: Magnes Press.

Kaplan, Joseph. 1980. “Rabbi Saul Levi Morteira's Treatise ‘Arguments against the Christian Religion'." Immanuel 11: 95-112; 
-—- 1982. mi-Nașrut lə-Yahadut: Ḥayav šel ha-'Anus Yișhaq ben 'Orobyo de Qastro [From Christianity to Judaism: The life and work of Isaac Orobio de Castro]. Jerusalem: Magnes Press.

Kellner, Menachem. 1986. Dogma in Medieval Jewish Thought. Oxford University Press.

Kreisel, Howard. 2001. Prophecy: The History of an Idea in Medieval Jewish Philosophy. Dordrecht: Kluwer Academic Publishers.

Lasker, Daniel J. 1977. Jewish Philosophical Polemics against Christianity in the Middle Ages. New York: Ktav Publishing House.

- - . 1980. “Torat ha-'Imut bə-Mišnato ha-Filosofit šel R. Yosef Albo." [Joseph Albo's Theory of Verification] Daat 5: 5-12.

_- - 1990. "Proselyte Judaism, Christianity, and Islam in the Thought of Judah Halevi." The Jewish Quarterly Review 81: 1-2, 75-91.

_- - 1994. “kə-neged mi hitpalmes Rav Sa'adya Ga’on be-Diyuno beVițul ha-Tora?" [Against Whom did Saadia Polemicize Concerning Abrogation of the Torah?] Daat 32-33: 5-11.

- - - 1991. "The Jewish Critique of Christianity under Islam in the Middle Ages." Proceedings of the American for Jewish Research 57: 121-153.

_- _. 1999. "Major Themes of the Jewish-Christian Debate." In The Solomon Goldman Lectures, Vol. VII, edited by Phillip Bell, 107130. Chicago: The Spertus Institute of Jewish Studies Press.

_-_. 2006. "Jewish Anti-Christian Polemics in the Early Modern Period: Change or Continuity." In Tradition, Heterodoxy and Religious Culture: Judaism and Christianity in the Early Modern Period, edited by Chanita Goodblatt, and Howard Kreisel, 469-488. Beersheba: Ben-Gurion University of the Negev Press. 
- - - 2010. "Rashi and Maimonides on Christianity." In Between Rashi and Maimonides: Themes in Medieval Jewish Thought, Literature and Exegesis, edited by E. Ephraim Kanarfogel, and Moshe Sokolow, 3-19. New York: Yeshiva University Press.

Lasker, Daniel J., and Sarah Stroumsa. 1996. The Polemic of Nestor the Priest: Introduction, Translation and Commentary. Jerusalem: Ben-Zvi Institute.

Limor, Ora. 1994. Die Disputationen zu Ceuta (1179) und Mallorca (1286): Zwei Antijudische Schriften aus dem mittelalterlichen Genua. München: Monumenta Germaniae Historica, Quellen zur Geistesgeschichte des Mittelalters.

_-_. 2003. “ba-'Armon bə-Barsșelona u-ba-Šuq bə-Mayorqa: Liqrat tipologya Ḥadaša Šel Vikuhḥe ha-Dat bi-Yeme ha-Benayim." [In the Palace of Barcelona and in the Market of Mallorca: Toward a New Typology of Religious Disputations in the Middle Ages] Pe'emim: 94-95, 105-134.

-_- 2010. "Polemical varieties: Religious disputations in 13th century Spain." Iberia Judaica 2: 55-79.

Lipiner, Eliyahu. 1982. “Yəhude Fes b-Me’a ha-Šeš-'Esre be-'Enav šel Xroniqa'i Portugali Ben Doram" [The Jews of Fes in the Sixteenth Century Through the Eyes of a Portuguese Chronicler] In Morešet Yəhude Səfarad ve-ha-Mizrah - Mehqqarim [The Sepharadi and Oriental Jewish Heritage Studies], edited by Yissaschar Ben Ami, 13-24. Jerusalem: Magnes Press.

Melnick, Ralph. 1981. From Polemics to Apologetics: Jewish-Christian Rapprochement in 17th Century Amsterdam. Assen: Van Gorcum. Nizri, Yigal G. 2014. "Sharifan Subjects, Rabbinic Texts: Moroccan Halakhic Writing, 1860-1918." PhD diss., New York University. 
Ohana, Michal. 2014. "The Philosophy of R. Shaul Shemuel Serero: A Chapter of the History of Jewish Philosophy in Morocco." PhD diss., Bar-Ilan University.

Profiat Duran. 1981a. "'Al Təhi Kə-'Avotayix." [Be not like unto thy Fathers] In Talmge 1981, 73-83.

- - . 1981b. "Klimat ha-Goyim." [The Reproach of the Gentiles] In Talmge 1981, 3-66.

Regev, Shaul. 2010. Dəraša ha-Məsura və-ha-kətuva: Dərašot u-Daršanim bi-Yəme ha-Benayim [Oral and Written Sermons in the Middle Ages]. Jerusalem: Reuven Mass Publishing.

Rosenberg, Shalom. 1983. "Exile and Redemption in Jewish Thought in the Sixteenth Century: Contending Conceptions." In Jewish Thought in the Sixteenth Century, edited by Bernard Dov Cooperman, 399-430. Cambridge: Harvard University Press.

Saadia Gaon. 1948. The Book of Beliefs and Opinions, translated by Samuel Rosenblatt. New Haven: Yale University Press.

Sack, Bracha. 1980. “Galut ve-Geula in Bərit Ha-Levi lə-Rav Šəlomo Al-Qabeș." [Exile and redemption in Berit Halevi of R. Solomon Alkabez] Eshel Beer-Sheva (II), 265-286.

_-_. 1995. bə-Ša'are ha-Qabala šel Rabi Moše Qordovero [The Kabbalah of Rabbi Moshe Cordevero]. Beer-Sheva: Ben Gurion University Press.

Saperstein, Marc. 1989. Jewish Preaching 1200-1800: An Anthology. New Haven: Yale University Press.

Schwartz, Dov. 1994. “R. Yehuda Halevi 'al ha-Nașrut və-'al ha-Mada' haNisyoni." [Rabbi Yehuda Halevi on Christianity and Experimental Science] AJS Review 19 (1): 1-24. 
Schwartz, Dov. 2005. Ha-ra‘ayon Haməšihi Bə-hagut Ha-yəhudit Bime Ha-benaim [Messianism in Medieval Jewish Thought]. Ramat Gan: Bar-Ilan University Press.

Serero, Shaul. 1989. Dəruše mə-ha-Rašaš Serero [Sermons by R. Serero], compiled by David Ovadia. Jerusalem.

Stroumsa, Sarah, ed. 1989. Dawud Ibn Marwan al-Muqammis's Twenty Chapters. Leiden: Brill.

_- - 1997. "Jewish polemics against Islam and Christianity in the light of Judaeo-Arabic texts." In Judaeo-Arabic Studies; Proceedings of the Founding Conference of the Society for Judaeo-Arabic Studies, edited by Norman Golb, 241-250. Amsterdam: hardwood academic publishers.

Szpiech, Ryan. 2013. Conversion and Narrative: Reading and Religious Authority in Medieval Polemic. Philadelphia: University of Pennsylvania Press.

Talmge, Frank, ed. 1981. Kitve Polmus lə-Profiyat Duran: Kəlimat Goyim ve-'Igeret 'Al Təhi Ka-'Avotexa [The Polemical Writings Of Profiat Duran: The Reproach of the Gentiles and 'Be not like unto thy Fathers']. Jerusalem: The Zalman Shazar Center.

Wilke, Carsten L. 2014. The Marrakesh Dialogues: A Gospel Critique and Jewish Apology From the Spanish Renaissance. Leiden: Brill.

Wolfson, Harry A. 1975. "Saadia on the Semantic Aspect of the Problem of Attributes." In Salo W. Baron Jubilee, vol. 2., 1009-1021. Jerusalem: American Academy for Jewish Research.

- - . 1997. "Saadia on the Trinity and Incarnation." In Studies in the History of Philosophy and Religion, vol. 2, edited by Isadore Twersky, 393-414. Cambridge, Mass. \& London: Harvard University Press. 
Yahya, Dahiru. 1981. Morocco in the Sixteenth Century: Problems and Patterns in African Foreign Policy. Essex: Longman House.

Yuval, Yisrael. 1994. “Niqmat ha-Šem hi Niqmat Hexalo." ['The Lord Will Take Vengeance, Vengeance for His Temple' - Historia sine ira et studio] Zion 59: 351-414.

_-_. 1996. "ha-Posḥim 'al šte ha-Sə'ifim: ha-Hagada šel Pesaḥ." [The Haggadah of Passover and Easter] Tarbitz 65: 5-28. 